\section{Identification of Peach Rootstock Cultivars by RAPD Markers}

\author{
Zhen-Xiang Lu, G.L. Reighard, and W.V. Baird \\ Department of Horticulture, Clemson University, Clemson, SC 29634-0375
}

\author{
A.G. Abbott and S. Rajapakse \\ Department of Biological Sciences, Clemson University, Clemson, \\ SC 29634-0375
}

Additional index words. DNA fingerprint, genetic relatedness, Prunus persica

\begin{abstract}
Eighteen peach rootstock cultivars, most of Prunus persica (L.) Batsch, were screened for diagnostic random amplified polymorphic DNA (RAPD) markers using synthetic decamer oligonucleotide primers. Twenty of the 80 primers were informative, and 40 amplified DNA bands from the informative primers were selected as RAPD markers. Based on combined banding patterns, all 18 rootstock cultivars were identified with only six of the 20 informative primers. Cluster analysis of the 18 peach rootstock cultivars using 40 RAPD markers produced a dendrogram of genetic relatedness in good agreement with their putative pedigrees. The first major bifurcation in the dendrogram divided these rootstock cultivars into two groups according to their resistance or susceptibility to root-knot nematodes [Meloidogyne incognita (Kofoid and White) Chitwood and M. javanica (Treub) Chitwood].
\end{abstract}

Identifying plant cultivars by molecular fingerprinting procedures is becoming a practical necessity (Smith and Smith, 1992). The relatively narrow range of morphological traits and limited number of polymorphic isoenzyme systems are not adequate to discriminate all the cultivars of any given species. Furthermore, many phenotypic traits are developmentally regulated or influenced by the genotype $\times$ environment interaction. However, with the advent of DNA-based genetic markers, such as restriction fragment length polymorphisms (RFLP) and random amplified polymorphic DNAs (RAPD), the fingerprinting of plant cultivars has become more efficient, reliable, and useful (Caetano-Anolles et al., 1991; Nybom, 1994).

In horticultural crops, RFLP markers have been used successfully to identify cultivars of a wide variety of species (Bowers et al., 1993; Hubbard et al., 1992; Lavi et al., 1991; Nybom et al., 1989; Parent and Page, 1992; Tzuri et al., 1991; Vainstein and Ben-Meir, 1994; Vosman et al., 1992). Recently, a modification of the automated polymerase chain reaction (PCR) has created another class of molecular markers-RAPDs (Williams et al., 1990). Compared to RFLPs, the RAPD procedure is a fast, sensitive method that avoids using radioactive isotopes and is well suited for studies of many samples (Thormann and Osborn, 1992). There-

Received for publication 30 June 1995. Accepted for publication 29 Sept. 1995. We sincerely thank T.G. Beckman (Agricultural Research Service-U.S Dept. of Agriculture, Fruit and Nut Tree Research Laboratory Byron, Ga.) for providing peach rootstock germplasm and W.C. Bridges (Dept. of Experimental Statistics, Clemson Univ., Clemson, S.C.) for assistance with the cluster analysis. The cost of publishing this paper was defrayed in part by the payment of page charges. Under postal regulations, this paper therefore must be hereby marked advertisement solely to indicate this fact. fore, RAPD analysis can be used to identify many useful polymorphisms quickly and efficiently, and as such, it has tremendous potential for use in cultivar identification. For example, a number of apple (Malus domestica Borkh.) (Koller et al., 1993), red raspberry (Rubus idaeus L.) (Graham et al., 1994), and rose (Rosa spp.) cultivars (Torres et al., 1993) have been fingerprinted recently using RAPD markers.

RFLP and RAPD markers have been used in peach genetics and breeding programs (Chaparro et al., 1994; Dirlewanger and Bodo, 1994; Eldredge et al., 1992; Rajapakse et al., 1995), mainly to construct genomic linkage maps and to tag loci encoding important phenotypic traits in peaches. Only a few scion cultivars have been distinguished by RFLP markers (Rajapakse et al., 1995). Because it is relatively difficult to observe morphological traits of a rootstock cultivar after grafting, DNA markers greatly facilitate rootstock idensize (kilobase pairs). tification. Our primary objective was to use the PCR-based RAPD analysis to identify markers that distinguish peach rootstock cultivars important in commercial production. In addition, cluster analysis of the markers was used to examine genetic relatedness of these rootstock cultivars.

\section{Materials and Methods}

Eighteen peach rootstock cultivars, most of $P$. persica, were selected for DNA fingerprinting. All of these rootstock cultivars were propagated vegetatively and were maintained as clones at the Clemson Univ. Sandhill Research and Education Center, Columbia, S.C., and the Agricultural Research Service-U.S. Dept. of Agriculture (ARS-USDA) Fruit and Nut Tree Research Laboratory, Byron, Ga. Young leaves ( $<4$ weeks old) were collected from each clone of Lovell, Nemaguard, Halford, Higama, Montclar, Tennessee Natural (Selection no. 281-1), Boone County, Flordaguard, and GF305 in May 1994 at the Clemson Univ. Sandhill Research and Education Center. Similarly, young leaves ( $<6$ weeks old) were collected from each clone of SL1089 (selection of BY520-9 open-pollinated seedlings), SL1090 (selection of BY520-9 openpollinated seedlings), Lovell, Nemaguard, Nemared, Rubira, Bailey, Harrow Blood, Siberian C, Yunnan, and Okinawa in July 1994 at the ARS-USDA Fruit and Nut Tree Research Laboratory. All leaf samples were refrigerated during transportation to the laboratory and subsequently were stored at $-80 \mathrm{C}$ until processed.

Genomic DNA was isolated from the leaf samples using a salt-extraction method (Eldredge et al., 1992). DNA concentrations in the extractions were measured using a minifluorometer (Hoefer Scientific, San Francisco). Working solutions of genomic DNA at 10 ng. $\mu \mathrm{l}^{-1}$ in distilled $\mathrm{H}_{2} \mathrm{O}$ were prepared. DNA amplifications were performed in a volume of $25 \mu$, containing $15 \mathrm{ng}$ of template DNA, 0.2 $\mu \mathrm{M}$ of a decamer oligonucleotide primer (Operon Technologies, Almeda, Calif.), 0.75 unit Taq DNA polymerase (Perkin-Elmer/Cetus, Norwalk, Conn.), $5 \mathrm{~mm} \mathrm{MgCl}_{2}$, and $200 \mu \mathrm{M}$

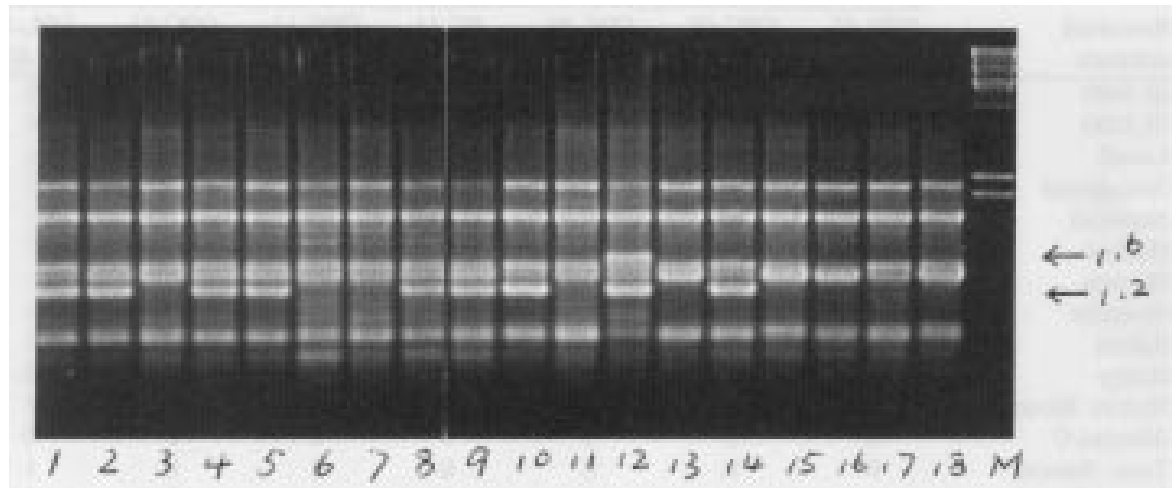

Fig. 1. DNA banding pattern produced by OPC-09 primer in 18 peach rootstock cultivars: (1) SL1089; (2) SL1090; (3) Lovell; (4) Nemaguard; (5) Nemared; (6) Halford; (7) Higama; (8) Montclar; (9) Rubira; (10) Bailey; (11) Harrow Blood; (12) Siberian C; (13) Tennessee Natural 281-1;(14) Boone County; (15) Flordaguard; (16) GF 305; (17) Yunnan; and (18) Okinawa. M indicates molecular markers of lambda DNA digested with Hind III enzyme. Arrows indicate the informative markers, and the numbers are their 
dNTP (Perkin-Elmer/Cetus) in reaction buffer [10 mm Tris-HCl (pH 8.3), 50 mм KCl]. Amplifications were performed in an automated thermal cycler (model 480; Perkin-Elmer/Cetus) programmed for 45 cycles of 1 min at $94 \mathrm{C}$, $1 \mathrm{~min}$ at $36 \mathrm{C}$, and $2 \mathrm{~min}$ at $72 \mathrm{C}$ (Rajapakse et al., 1995). Amplified products were sizefractioned by electrophoresis in $1.5 \%$ agarose gels (Tris-boric acid-EDTA buffer, $\mathrm{pH}$ 8.0), and DNA bands were visualized by ethidium bromide staining.

Eighty decamer primers, 20 from each of kits A, C, L, and Z (Operon Technologies), were used to screen for RAPD markers in the 18 peach rootstock cultivars. Only distinct, clearly resolved and polymorphic amplified DNA bands were scored. The ability of the amplification products to be reproduced was tested twice for each primer on template DNA from two independent extractions of each sample. Consistency of the DNA banding pat-

Table 1. Informative primers and corresponding RAPD markers for 18 peach rootstock cultivars

\begin{tabular}{|c|c|}
\hline Primer $^{2}$ & $\begin{array}{l}\text { Marker size(s) } \\
\text { (kilobase pairs) }\end{array}$ \\
\hline OPA-05 & 1.4 \\
\hline OPA-06 & 0.8 \\
\hline OPA-08 & $1.0,1.6,1.8$ \\
\hline OPA-12 & 1.9 \\
\hline OPA-14 & $1.3,1.9$ \\
\hline OPC-01 & 1.8 \\
\hline OPC-03 & $1.8,2.0$ \\
\hline OPC-04 & $0.8,1.7$ \\
\hline OPC-09 & $1.2,1.6$ \\
\hline OPC-11 & $1.3,1.4,1.8$ \\
\hline OPC-20 & $1.1,1.2$ \\
\hline OPL-12 & $1.0,1.4$ \\
\hline OPL-13 & $1.6,1.9,2.0$ \\
\hline OPL-17 & $0.6,0.8,1.0$ \\
\hline OPL-20 & 1.0 \\
\hline OPZ-01 & 1.8 \\
\hline OPZ-05 & $0.4,1.5$ \\
\hline OPZ-07 & $1.6,1.9$ \\
\hline OPZ-08 & $1.4,1.5,1.8$ \\
\hline OPZ-09 & $1.7,1.8,2.2$ \\
\hline
\end{tabular}

${ }^{2}$ Primer designations refer to the kit (last letter) and the specific primer (-number) purchased from Operon Technologies (OP). terns within a clone was confirmed with Lovell and Nemaguard clones maintained at two locations (Columbia and Byron). Only reproducible, informative DNA bands were selected for use as RAPD markers and retained for further analysis.

Cluster analysis of these RAPD markers from the 18 peach rootstock cultivars was performed by using the statistical analysis system (SAS Institute, 1988). According to the presence (1) or absence (0) of amplified DNA bands, a pairwise distance matrix was constructed by the distance index $\mathrm{F}=1-$ $(2 \mathrm{Nab}) /(\mathrm{Na}+\mathrm{Nb})$, where $\mathrm{Nab}=$ number of shared bands between a pair of genotypes a and $\mathrm{b}, \mathrm{Na}=$ number of scored bands in genotype a, and $\mathrm{Nb}=$ number of scored bands in genotype b (Nei and Li, 1979). The corresponding cluster analysis was performed based on the distance indices for each pair of rootstock cultivars, and the dendrogram of their genetic relatedness was generated with normalized average distances (NAD) between clusters.

\section{Results and Discussion}

Eighteen peach rootstock cultivars were screened for RAPD markers using single synthetic oligonucleotide primers in a PCR-based DNA amplification procedure. Although most primers produced banding patterns that were easily scored, only relatively few amplified DNA bands were clearly distinct, polymorphic, and reproducible (Fig. 1); these bands were scored and used for fingerprinting. Of the 80 primers tested, 20 were determined to be informative (Table 1), and 40 amplified DNA bands were selected as RAPD markers and were used in subsequent analyses.

Based on combined banding patterns, all 18 peach rootstock cultivars were identified by using only six of the 20 informative primers (OPC-03, OPC-09, OPC-11, OPL-13, OPL20, and OPZ-09) (Table 2). For example, with primer OPL-13, the 18 rootstock cultivars initially were divided into four groups: 1)
SL1089, SL1090, and Bailey; 2) Lovell, Halford, Montclar, Rubira, and Flordaguard; 3) Nemaguard, Nemared, Siberian C, Yunnan, and Okinawa; and 4) Higama, Harrow Blood, Tennessee Natural 281-1, Boone County, and GF 305 . From there, each group can be subdivided further by using other primers. All of these rootstock cultivars can be discriminated by four subsequent amplification steps.

Peach rootstock cultivars normally are maintained as clones and propagated vegetatively during their introduction; however, only open-pollinated seeds are used to produce rootstock seedlings in the commercial nursery industry. Variation in seedling populations of some rootstock cultivars has been reported (Layne, 1987); therefore, the RAPD markers used to identify clonal rootstock cultivars may not be suitable for fingerprinting their seedlings. Additional studies are necessary to determine the relationship of DNA markers identified for clonal rootstock cultivars and the corresponding patterns in $\mathrm{F}_{1}$ offspring before fingerprinting rootstocks of orchard trees can be applied practically to determine maternal parentage.

Cluster analysis of 40 RAPD markers from the 18 peach rootstock cultivars produced a dendrogram of genetic relatedness in good agreement with their putative pedigrees (Fig. 2). SL1089 and SL1090, recent selections derived from a common parent (BY520-9) (Okie et al., 1994), clustered together with the NAD of 0.28 . Similarly, the NAD between Lovell and Halford, which is assumed to have originated from a chance seedling of Lovell, was only 0.18 . The clustering of Boone County with Harrow Blood (0.22 NAD) implies a high level of genetic relatedness between these genotypes. The rootstock cultivars Nemaguard, considered a hybrid of $P$. persica and $P$. davidiana (Carr.) Franch (Okie et al., 1985), and Nemared, a red-leaf $\mathrm{F}_{3}$ seedling of Nemaguard (Ramming and Tanner, 1983), had a relatively small NAD.

The first major bifurcation in the dendrogram divided the 18 peach rootstock cultivars

Table 2. Identification of 18 peach rootstock cultivars by the presence (1) or absence (0) of selected RAPD markers from six primers.

\begin{tabular}{|c|c|c|c|c|c|c|c|c|c|c|c|}
\hline \multirow[b]{2}{*}{$\begin{array}{l}\text { Rootstock } \\
\text { cultivars }\end{array}$} & \multirow[b]{2}{*}{$\begin{array}{c}\text { OPC-03 } \\
(1.8)\end{array}$} & \multirow[b]{2}{*}{$\begin{array}{c}\text { OPC-09 } \\
(1.2)\end{array}$} & \multicolumn{9}{|c|}{ RAPD markers ${ }^{2}$} \\
\hline & & & $\begin{array}{c}\text { OPC-09 } \\
(1.6)\end{array}$ & $\begin{array}{c}\text { PC-11 } \\
(1.3)\end{array}$ & $\begin{array}{c}\text { OPC-11 } \\
(1.4)\end{array}$ & $\begin{array}{c}\text { OPC-11 } \\
(1.8)\end{array}$ & $\begin{array}{c}\text { OPL-13 } \\
(1.6)\end{array}$ & $\begin{array}{c}\text { OPL-13 } \\
(1.9)\end{array}$ & $\begin{array}{c}\text { OPL-13 } \\
(2.0)\end{array}$ & $\begin{array}{c}\text { OPL-20 } \\
(1.0)\end{array}$ & $\begin{array}{c}\text { OPZ-09 } \\
(1.7)\end{array}$ \\
\hline$\overline{\text { SL1089 }}$ & 0 & 1 & 0 & 1 & 0 & 0 & 0 & 1 & 0 & 1 & 1 \\
\hline SL1090 & 0 & 1 & 0 & 1 & 0 & 0 & 0 & 1 & 0 & 0 & 1 \\
\hline Lovell & 1 & 0 & 0 & 0 & 1 & 0 & 1 & 0 & 1 & 0 & 1 \\
\hline Nemaguard & 0 & 1 & 0 & 1 & 0 & 1 & 0 & 0 & 1 & 1 & 0 \\
\hline Nemared & 0 & 1 & 0 & 0 & 0 & 1 & 0 & 0 & 1 & 0 & 0 \\
\hline Halford & 1 & 0 & 0 & 0 & 1 & 0 & 1 & 0 & 1 & 0 & 0 \\
\hline Higama & 0 & 0 & 0 & 1 & 0 & 0 & 1 & 1 & 0 & 1 & 1 \\
\hline Montclar & 1 & 1 & 0 & 0 & 1 & 0 & 1 & 0 & 1 & 0 & 1 \\
\hline Rubira & 1 & 1 & 0 & 1 & 0 & 0 & 1 & 0 & 1 & 0 & 1 \\
\hline Bailey & 1 & 1 & 0 & 0 & 1 & 0 & 0 & 1 & 0 & 0 & 0 \\
\hline Harrow Blood & 1 & 0 & 0 & 0 & 1 & 0 & 1 & 1 & 0 & 0 & 0 \\
\hline Siberian C & 0 & 1 & 1 & 1 & 0 & 1 & 0 & 0 & 1 & 0 & 1 \\
\hline Tenn. Natural & 0 & 0 & 0 & 0 & 1 & 0 & 1 & 1 & 0 & 0 & 0 \\
\hline Boone County & 1 & 1 & 0 & 0 & 1 & 0 & 1 & 1 & 0 & 0 & 0 \\
\hline Flordaguard & 1 & 0 & 0 & 1 & 0 & 1 & 1 & 0 & 1 & 0 & 0 \\
\hline GF 305 & 1 & 0 & 0 & 1 & 1 & 0 & 1 & 1 & 0 & 0 & 0 \\
\hline Yunnan & 0 & 0 & 0 & 1 & 0 & 0 & 0 & 0 & 1 & 0 & 1 \\
\hline Okinawa & 0 & 0 & 0 & 1 & 0 & 1 & 0 & 0 & 1 & 1 & 1 \\
\hline
\end{tabular}

${ }^{2}$ Marker notation refers to the kit (last letter) and the primer (-number) purchased from Operon Technologies (OP). The number in parentheses refers to the size (kilobase pairs) of amplified DNA fragment. 


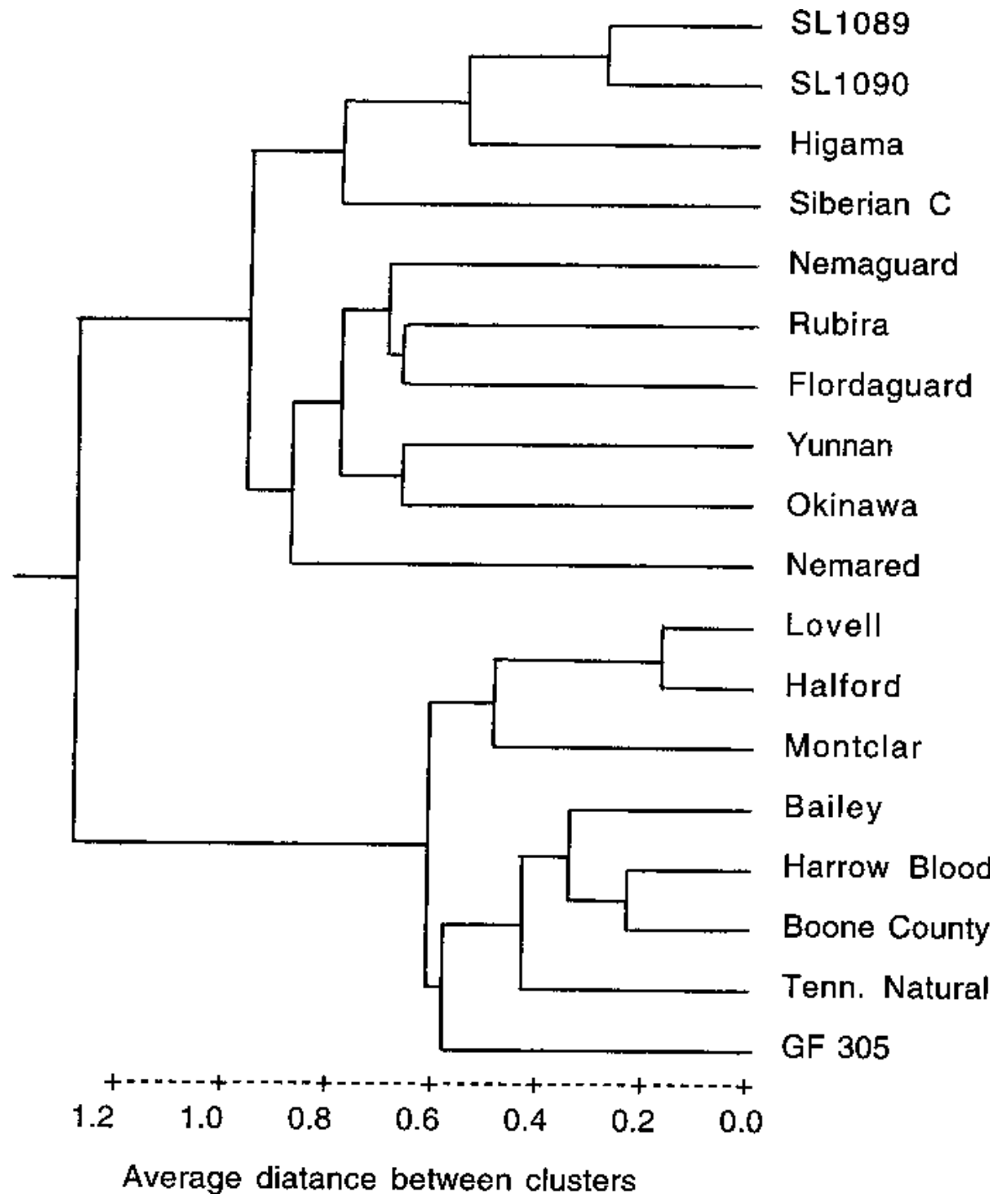

Fig. 2. Dendrogram of the genetic relatedness of 18 peach rootstock cultivars based on 40 RAPD markers.

into two groups. One group (Lovell, Halford, Montclar, Bailey, Harrow Blood, Boone County, Tennessee Natural, and GF 305) is susceptible to root-knot nematodes, whereas the second group (SL1089, SL1090, Higama, Nemaguard, Flordaguard, Yunnan, Okinawa, and Nemared), with the exception of Rubira and Siberian C, is resistant or tolerant (Layne, 1987) to root-knot nematodes. The breakout into these two groups is probably due to the common parentage used in root-knot nematode breeding programs and the genes linked to root-knot nematode resistance. However, it is highly improbable that root-knot nematode resistance genes were marked in this study.

Different genotypes can be characterized by using molecular markers independent of the influences of environmental conditions, developmental stages, or sources of tissue being analyzed (Smith and Smith, 1992). Our results showed that RAPD markers are useful for identifying peach rootstock cultivars. Future applications lie in using these markers to tag commercially important traits.

\section{Literature Cited} 1993. DNA fingerprint characterization of some wine grape cultivars. Amer. J. Enol. Viticult. 44(3):266-274.

Caetano-Anolles, G., B.J. Bassam, and P.M Bresshoff. 1991. DNA amplification fingerprinting: A strategy for genome analysis. Plant Mol. Biol. Rptr. 9(4):294-307.

Chaparro, J.X., D.J. Werner, D. O'Malley, and R.R. Sederoff. 1994. Targeted mapping and linkage analysis of morphological isozyme and RAPD markers in peach. Theor. Appl. Genet. 87:805815 .

Dirlewanger, E. and C. Bodo. 1994. Molecular genetic mapping of peach. Euphytica 77:101103

Eldredge, L., R. Ballard, W.V. Baird, A. Abbott, P. Morgens, A. Callahan, and R. Monet. 1992. Application of RFLP analysis to genetic linkage mapping in peaches. HortScience 27:160-163.

Graham, J., R.J. McNicol, K. Gerig, and W.T.G. Vandeven. 1994. Identification of red raspberry cultivars and an assessment of their relatedness using fingerprints produced by random primers. J. Hort. Sci. 69(1):123-130.
Bowers, J.E., E.B. Bandman, and C.P. Meredith
Hubbard, M., J. Kelly, S. Rajapakse, A. Abbott, and R. Ballard. 1992. Restriction fragment length polymorphism in rose and their use for cultivar identification. HortScience 27:172-173.

Koller, B., A. Lehmann, J.M. McDermott, and C. Gessler. 1993. Identification of apple cultivars using RAPD markers. Theor. Appl. Genet. 85:901-904

Lavi, U., J. Hillel, A. Vainstein, E. Lahav, and D. Sharon. 1991. Application and genetic analysis of avocado. J. Amer. Soc. Hort. Sci. 116:10781081.

Layne, R.E.C. 1987. Peach rootstocks, p. 185-216. In: R.C. Rom and R.F. Carlson (eds.). Rootstocks for fruit crops. Wiley, New York.

Nei, M. and W. Li. 1979. Mathematical model for studying genetic variation in terms of restriction endonucleases. Proc. Natl. Acad. Sci. USA 76(10):5269-5273.

Nybom, H. 1994. DNA [sic] fingerprintng-A useful tool in fruit breeding. Euphytica 77:59-64.

Nybom, H., B.A. Schaal, and S.H. Rogstad. 1989. DNA "fingerprints" can distinguish cultivars of blackberries and raspberries. Acta Hort. 262:305-310.

Okie, W.R., T.G. Beckman, A.P. Nyczepir, G.L. Reighard, W.C. Newall, Jr., and E.I.Zehr. 1994. BY520-9, A peach rootstock for the southeastern United States that increases scion longevity. HortScience 29:705-706.

Okie, W.R., D.W. Ramming, and R. Scorza. 1985. Peach, nectarine, and other fruit breeding by the USDA in the last two decades. HortScience 20:633-641.

Parent, J. and D. Page. 1992. Identification of raspberry cultivars by nonradioactive DNA fingerprinting. HortScience 27:1108-1110.

Rajapakse, S., L.E. Belthoff, G. He, A.E. Estager, R Scorza, I. Verde, R.E. Ballard, W.V. Baird, A. Callahan, R. Monet, and A.G. Abbott. 1995. Genetic linkage mapping in peach using morphological, RFLP and RAPD markers. Theor. Appl. Genet. 90:503-510.

Ramming, D.W. and O. Tanner. 1983. 'Nemared' peach rootstock. HortScience 18:376.

SAS Institute. 1988. SAS user guide. SAS Inst., Cary, N.C.

Smith, J.S.C. and O.S. Smith. 1992. Fingerprinting crop varieties. Adv. Agron. 47:85-140.

Thormann, C.E. and T.C. Osborn. 1992. Use of RAPD and RFLP markers for germplasm evaluation. In: Applications of RAPD technology to plant breeding, p. 9-11. Joint Plant Breeding Symp. Ser. Crop Sci. Soc. Amer., Amer. Soc. Hort. Sci., and Amer. Genet. Assn., Minneapolis, 1 Nov. 1992

Torres, A.M., T. Millan, and J.I. Cubero. 1993. Identifying rose cultivars using random amplified polymorphic DNA markers. HortScience 28:333-334.

Tzuri, G., J. Hillel, U. Lavi, A. Haberfeld, and A. Vainstein. 1991. DNA fingerprint analysis of ornamental plants. Plant Sci. 76:91-97.

Vainstein, A. and H. Ben-Meir. 1994. DNA fingerprint analysis of roses. J. Amer. Soc. Hort. Sci. 119:1099-1103.

Vosman, B.,P. Arens, W. Rus-Kortekaas, and M.J.M Smulders. 1992. Identification of highly polymorphic DNA regions in tomato. Theor. Appl. Genet. 85:239-244.

Williams, J.G.K., A.R. Kubelik, K.J. Livak, J.A Rafalski, and S.V. Tingey. 1990. DNA polymorphisms amplified by arbitrary primers are useful as genetic markers. Nucleic Acids Res. 18:6531-6535. 